\title{
Perbandingan Nilai Prediktif antara Risk-of-Malignancy Index (RMI) dan Klasifikasi IOTA Simple Rules dalam Prediksi Keganasan pada Kasus Tumor Ovarium di RSUP Dr. Hasan Sadikin Bandung
}

\author{
Huda Toriq, Yudi Mulyana Hidayat, Dodi Suardi \\ Departemen Obstetri dan Ginekologi Fakultas Kedokteran Universitas Padjadjaran/ \\ RSUP Dr. Hasan Sadikin Bandung \\ Korepondensi: Huda Toriq, Email: hud@toriq.net
}

\begin{abstract}
Abstrak
Tujuan: Penelitian ini bertujuan untuk mengevaluasi dan membandingkan penerapan dua metode diagnostik yang telah digunakan di RSHS, yaitu skor RMI dan Klasifikasi IOTA Rules untuk memprediksi keganasan suatu tumor ovarium selama periode 2017-2018

Metode: Penelitian ini merupakan penelitian komparatif dengan pengambilan data secara retrospektif. Sumber data diperoleh dari rekam medis pasien yang menjalani operasi pengangkatan dan pemeriksaan histopalogis tumor ovarium. Dilakukan pengumpulan informasi mengenai data USG, kadar CA125, skor RMI, klasifikasi IOTA Simple Rules, dan membandingkannya dengan luaran histopatologis.

Hasil: 190 kasus tumor ovarium diteliti. 156 kasus $(82,1 \%)$ memiliki luaran histopatologis ganas dan 34 kasus lainnya (17.9\%) jinak. 178 kasus $(93,68 \%)$ memiliki skor RMI $\geq 200$ dan 12 kasus $(6,32 \%)<200$. sebanyak 78 kasus diklasifikasikan sebagai Malignant, 42 kasus Benign, dan 70 kasus lainnya Inconclusive dengan kriteria IOTA Simple Rules. Distribusi CA125 dan Skor RMI pada kedua kelompok luaran histopatologis berbeda secara bermakna $(\mathrm{P}<0,05)$. Sensitivitas dan spesifisitas klasifikasi IOTA Simple Rules di RSHS masing-masing 94,23\% dan 97,06\%, dengan menggabungkan kelompok IOTA inkonklusif dengan kelompok ganas. Penghitungan sensitivitas dan spesifisitas skor RMI memberikan nilai 95,51\% dan 14,71\% dengan menggunakan cut-off-point skor RMI 200.

Kesimpulan: Sensitivitas dan spesifisitas klasifikasi IOTA Simple Rules lebih baik dibandingkan dengan skor RMI dalam memprediksi keganasan suatu tumor ovarium.
\end{abstract}

Kata Kunci: Karsinoma ovarium, IOTA, RMI, USG, CA125

\section{Predictive Value Comparison of Risk-of-Malignancy Index (RMI) and IOTA Simple Rules in Predicting Ovarian Tumor Malignancy in Dr. Hasan Sadikin Hospital Bandung}

\begin{abstract}
Objective: This study was done to evaluate and compare the use of RMI score \& IOTA Simple Rule which has been routinely used in Hasan Sadikin Hospital to predict ovarian malignancy in 2017-2018

Methods: This is a comparative study that collects data retrospectively. Data was obtained from medical record of patient who underwent ovarian tumor surgery, including USG report, CA125, RMI score, IOTA Simple Rules, and compared it with histopathological outcome.

Result: 190 ovarian tumor cases was studied. 156 cases (82.1\%) have malignant histopathological result and the other 34 cases (17.9\%) were benign. $178(93.68 \%)$ cases have RMI score $\geq 200$ and 12 cases $(6.32 \%)<200$. As much 78 cases were classified as malignant, 42 cases (22.11\%) were classified benign, and the other 70 cases were classified inconclusive using IOTA Simple Rules. CA125 and RMI Score distribution on both histopathological group differs significantly $(P<0.05)$. IOTA Simple Rules shows sensitivity and specificity of $94.23 \%$ and $97.06 \%$ respectively, when inconclusive and malignant results were grouped together. RMI Score showed sensitivity and specificity of $95.51 \%$ and $14.71 \%$ respectively using cut-off point of 200 .

Conclusion: IOTA Simple Rules performs better than RMI in predicting ovarian tumor malignancy.
\end{abstract}

Key words: Ovarian cancer, IOTA, RMI, USG, CA125 


\section{Pendahuluan}

Massa pelvis merupakan salah satu indikasi tersering rujukan ke bidang ginekologi. Sebagian dari massa pelvis tersebut merupakan keganasan dan membutuhkan tindakan operasi. Tumor ganas ovarium merupakan kanker penyebab kematian ke lima pada wanita di dunia, ${ }^{1}$ lebih dari 239.000 kasus baru dilaporkan setiap tahun. ${ }^{2}$ Tumor ganas ovarium memiliki 5 ysr terendah diantara di antara kasus-kasus keganasan di bidang ginekologi, tumor ganas ovarium memiliki 5-year survival rate terendah $(30-50 \%) .^{3}$

Prediksi preoperatif secara tepat apakah massa tersebut jinak atau ganas, dapat membuat seorang pasien yang didiagnosis dengan keganasan ovarium mendapatkan tindakan lini pertama yang sesuai. Hal tersebut juga mendorong pasien untuk memperoleh rujukan dan ditangani oleh ahli onkologi ginekologi, sehingga mengurangi penundaan tegaknya diagnosis histopatologi serta penatalaksanaan selanjutnya pasca operasi. Ultrasonografi dikenal luas sebagai modalitas pencitraan terbaik untuk mengevaluasi tumor ovarium. ${ }^{4}$ Cara paling akurat untuk menilai patologi massa ovarium secara ultrasonografis ialah dengan penilaian subyektif oleh pemeriksa yang berpengalaman. ${ }^{5}$ Karena subyektifitas dan pengalaman dari pemeriksa sangat bervariasi, telah dikembangkan berbagai model prediksi yang berbasis ultrasonografi untuk membantu para operator membedakan secara akurat massa jinak ataupun ganas. International Ovarian Tumour Analysis (IOTA) telah mengembangkan model simple rules yang berdasarkan lima fitur keganasan / malignancy (fitur M) dan lima fitur yang sugestif jinak / benign (fitur B). Jika satu atau lebih fitur $M$ ditemukan tanpa ditemukannya fitur B, massa diklasifikasikan sebagai ganas. Bila satu atau lebih fitur B ditemukan tanpa ditemukannya fitur $\mathrm{M}$, maka massa diklasifikasikan sebagai jinak. Apabila ditemukan fitur B dan $\mathrm{M}$ atau tidak ditemukan satu fitur pun, maka massa tidak dapat diklasifikasikan (inkonklusif). ${ }^{6}$

Sebagian studi menilai bahwa ultrasonografi saja tidak adekuat untuk aplikasi klinis penentuan tingkat keganasan preoperasi pada tumor ovarium. Metode kombinasi untuk mengevaluasi keganasan ovarium telah dikembangkan dan digunakan, Salah satunya ialah Risk-of-malignancy Index (RMI). RMI dihitung sebagai fungsi dari skor USG (U), status menopause (M), dan kadar CA 125 dengan rumus sebagai berikut:

$$
R M I=U \times M \times C A 125
$$

Pada tahun 1990, Jacob dkk secara bersama-sama mengembangkan RMI yang dikenal sebagai RMI 1. Peneliti lain kemudian mengembangkan versi lain dari RMI pada tahun 1996 yang dikenal sebagai RMI 2, dan di tahun 1999, Tingulstad dkk memodifikasi RMI yang dikenal sebagai RMI 3. Di tahun 2009, Yamamoto dkk menambahkan parameter ukuran tumor / size (S) ke dalam rumus RMI dan dikenal sebagai RMI $4 .{ }^{7}$

$$
R M I 4=U \times M \times S \times C A 125
$$

Penghitungan RMI score telah diterapkan dalam praktik di RSHS untuk memprediksi keganasan suatu tumor ovarium. Sejumlah kasus dijumpai yang memiliki nilai prediksi ganas secara pre operatif berdasarkan RMI skor namun memiliki luaran histopatologis jinak. Diagnostik ultrasonografi telah dilakukan oleh divisi onkologi ginekologi dengan menerapkan penghitungan IOTA Skor untuk deskripsi suatu massa tumor ovarium. Perlu dilakukan evaluasi terhadap penggunaan dua metode diagnostik ini dan hubungannya terhadap luaran ganas / jinaknya suatu massa secara histopatologis pasca operatif. Bagaimana perbandingan antara sensitivitas dan spesifisitas Risk-of- 
Malignancy Indeks dengan IOTA Simple Rules dalam memprediksi secara preoperatif risiko keganasan pada pada kasus-kasus tumor ovarium di RSUP Dr. Hasan Sadikin?

\section{Metode}

Penelitian ini merupakan penelitian komparatif dengan pengambilan data secara retrospektif. Sumber data diperoleh dari rekam medis pasien yang menjalani operasi pengangkatan ovarium di RSUP Dr. Hasan Sadikin. Diagnosis histopatologis digunakan sebagai penentu keganasan pada pasien.

Pengumpulan informasi tentang demografi pasien, hasil USG, status menopausal pasien, dan kadar serum CA125 dan dihitung Skor RMI dan IOTA Simple Rules-nya. Versi RMI yang digunakan di RSUP Dr. Sadikin ialah RMI 2 yang dihitung berdasarkan rumus berikut: $\mathrm{RMI}=\mathrm{U} \times \mathrm{M}$ $x$ CA 125. Di mana U ialah skor USG, M merupakan status menopause, dan CA 125 merupakan kadar Serum CA 125 pasien.

Skor USG didapatkan dengan cara menganalisis hasil pemeriksaan ultrasonografi pasien yang menjadi sampel penelitian. Dilakukan pendataan terhadap temuan gambaran-gambaran berikut: (1) lesi kistik multilokuler, (2) area padat, (3) lesi bilateral, (4) asites dan (5) metastasis abdominal. Temuan 0 atau 1 gambaran tersebut memberikan nilai skor $U=1$.

Temuan 2 atau lebih gambaran tersebut memberikan skorU $=4$. Status pascamenopaus didefinisikan sebagai keadaan amenorea lebih dari satu tahun atau usia lebih dari 50 tahun pada wanita-wanita yang telah menjalani histerektomi. Wanita di luar kriteria tersebut dikategorikan sebagai premenopaus. Pasien premenopaus diberikan skor $\mathrm{M}=1$ sedangkan pasien pascamenopaus diberikan skor $\mathrm{M}=4$. Kadar serum CA 125 pasien dikalkulasikan langsung ke dalam rumus RMI. Spesifisitas didefinisikan sebagai persentase pasien dengan luaran histopatologis jinak yang memiliki hasil negatif pada prediksi tingkat keganasan dengan RMI (skor RMI <200). Sensitivitas didefinisikan sebagai persentase pasien dengan dengan luaran histopatologis yang tergolongkan ganas yang memiliki hasil prediksi positif (skor RMI >200).

Pengelompokan gambaran USG secara IOTA dilakukan dengan melihat hasil USG pasien yang menjadi sampel penelitian. Dilihat lima fitur jinak/benign (B) dan lima fitur ganas/malign (M). Jika satu atau lebih fitur $\mathrm{M}$ ditemukan tanpa ditemukannya fitur B, massa diklasifikasikan sebagai ganas. Bila satu atau lebih fitur B ditemukan tanpa ditemukannya fitur M, maka massa diklasifikasikan sebagai jinak. Apabila ditemukan fitur B dan M atau tidak ditemukan satu fitur pun, maka massa tidak dapat diklasifikasikan (inkonklusif).

Sampel penelitian ini adalah seluruh pasien yang menjalani operasi pengangkatan massa ovarium di RSUP Dr. Hasan Sadikin periode 2017-2018 dan telah menjalani pemeriksaan USG di RSUP Dr. Hasan Sadikin serta telah diperiksa kadar CA-125 serumnya.

Besar sampel ditentukan berdasarkan rumus penentuan besar sampel untuk penelitian uji diagnostik dengan keluaran sensitivitas dengan mempertimbangkan nilai sensitivitas pemeriksaan dari penelitian sebelumnya sebesar $76 \%$ dengan memilih taraf kepercayaan $95 \%$ dan presisi $5 \%$. Angka kejadian atau prevalensi pada penelitian sebelumnya sebesar $30 \%$. Dengan menggunakan $\mathrm{Z} \alpha$ yang diperoleh dari tabel distribusi normal standar, didapat nilainya sesuai untuk $Z \alpha=1,96$, maka menggunakan rumus besar sampel didapatkan jumlah sampel minimal. Dengan menggunakan rumus penentuan besar sampel untuk penelitian uji diagnostik dengan keluaran sensitivitas, maka digunakan rumus besar sampel sebagai berikut, yaitu dengan :

$$
N=\frac{\left(Z_{\alpha}\right)^{2} \cdot \operatorname{Sen} \cdot(1-\operatorname{Sen})}{d^{2} \cdot P}
$$


$\mathrm{N}$ = Jumlah sampel yang dibutuhkan

$\mathrm{Z} \alpha=$ Nilai $\mathrm{Z}$ dari tabel distribusi normal untuk taraf kepercayaan $95 \%(Z=1,96)$

Sen $=$ Sensitivitas berdasarkan penelitian sebelumnya $(76 \%=0,76)$

$\mathrm{d}=$ Presisi $(5 \%)$

$\mathrm{P}=$ Prevalensi kejadian $(40 \%=0,4)$

Berdasarkan rumus di atas diperoleh :

$$
\begin{aligned}
& N=\frac{\left(Z_{\alpha}\right)^{2} \cdot \operatorname{Sen} \cdot(1-\operatorname{Sen})}{d^{2} \cdot P} \\
& N=\frac{(1,96)^{2} \cdot 0,76^{*}(1-0,76)}{0,05^{2} \cdot 0,4}
\end{aligned}
$$

$\mathrm{N}=182,3 \approx 183$

Berdasarkan perhitungan di atas, diperoleh jumlah total minimal sampel adalah 183 sampel penelitian. Pada data pengukuran skor RMI dan IOTA Simple Rules, masingmasing dihitung dan dideskripsikan nilainilai berikut:

- True positive (TP): Jumlah kasus dengan luaran histopatologis ganas yang pada diagnostik preoperatif dicurigai ganas.

- False positive (FP): Jumlah kasus dengan luaran histopatologis jinak namun pada diagnostik preoperatif dicurigai ganas.

- True negative (TN): Jumlah kasus yang pada diagnostik preoperatif dicurigai jinak dan secara histopatologik terbukti jinak.

- False negative (FN): Jumlah kasus yang pada diagnostik preoperatif dicurigai jinak namun secara histopatologis ganas.

- Sensitivitas (equivalen True Positive Rate): proporsi kasus ganas yang dideteksi dengan pemeriksaan. Secara matematis, sensitivitas dihitung dengan rumus: Sensitivitas $=\mathrm{TP} /(\mathrm{TP}+\mathrm{FN})$

- Spesifisitas (juga dikenal dengan istilah True Negative Rate) ialah proporsi kasus dengan luaran jinak yang dideteksi jinak dengan pemeriksaan preoperatif (RMI Skor $<200$ atau IOTA Rule Benign). Definisi secara matematis:
Spesifisitas $=\mathrm{TN} /(\mathrm{TN}+\mathrm{FP})$

Data yang diperoleh dicatat dalam formulir penelitian yang telah dibuat, kemudian dilakukan editing, verifikasi, coding dan data entry, selanjutnya dilakukan analisis data.

\section{Hasil}

Tabel 1 Karakteristik Sampel Penelitian

\begin{tabular}{lc}
\hline \multicolumn{1}{c}{ Variabel } & $\mathbf{N}=\mathbf{1 9 0}$ \\
\hline Usia & \\
Mean \pm Std & $44,00 \pm 14,036$ \\
Median & 44,50 \\
Range (min-max) & $13,00-81,00$ \\
Kategori Usia & \\
$<20$ tahun & $6(3,2 \%)$ \\
$20-40$ tahun & $62(32,6 \%)$ \\
$>40$ tahun & $122(64,2 \%)$ \\
CA125 & \\
Mean \pm Std & $641,57 \pm 1254,034$ \\
Median & 235,05 \\
Range (min-max) & $16,00-9934,00$ \\
RMI & \\
Mean \pm Std & \\
Median & $3750,16 \pm 10040,244$ \\
Range (min-max) & 882,30 \\
IOTA Simple Rule & $25,00-80000,00$ \\
Malignant & \\
Benign & $78(41,1 \%)$ \\
Inconclusive & $42(22,1 \%)$ \\
Klasifikasi Histopatologi & $70(36,8 \%)$ \\
Ganas & \\
\hline & $156(82,1 \%)$ \\
\hline Jinak & $34(17,9 \%)$ \\
\hline
\end{tabular}

Keterangan: Untuk data kategorik disajikan dengan jumlah/frekuensi dan persentase sedangkan data numerik disajikan dengan rerata, median, standar deviasi dan range.

Dari 190 kasus, didapatkan 122 pasien (64.2\%) berusia $>40$ tahun sedangkan 62 pasien $(32.6 \%)$ masuk dalam kelompok usia 20-40 tahun dan 6 lainnya (3.2\%) berusia di bawah 20 tahun. Dari sampel penelitian tersebut, terdapat 156 kasus $(82.1 \%)$ dengan luaran histopatologis pascaoperasi ganas 
dan 34 sisanya (17.9\%) jinak. Kadar CA125 pra operasi pada sampel bervariasi dengan mean $641.57 \pm 1254.034$ dan median 235.05. Setelah dilakukan perhitungan faktor-faktor menopause, skor USG dan kadar CA125, didapatkan 178 kasus $(93,68 \%)$ dengan skor RMI $\geq 200$ dan 12 kasus $(6,32 \%)$ dengan skor RMI <200. Sedangkan dengan klasifikasi IOTA Simple Rule, 78 kasus (41.1\%) masuk dalam klasifikasi Malignant, 42 kasus (22.1\%) diklasifikasikan Benign, dan 70 kasus (36.8\%) Inconclusive.

Sebaran usia, kadar CA-125, Skor RMI, dan kelompok IOTA Simple Rules terhadap luaran histopatologis disajikan pada Tabel 2. Analisis data numerik diuji dengan menggunakan uji $\mathrm{T}$ tidak berpasangan apabila data berdistribusi normal serta alternatif uji Mann Whitney apabila data tidak berdistribusi normal. Sebaran usia pada kedua kelompok luaran histopatologis tidak menunjukkan perbedaan bermakna. Kelompok ganas memiliki mean usia $44.17 \pm 13.660$ dan median 45.00 sedangkan mean dan median kelompok jinak berturut-turut $43.20 \pm 15.845$ dan $41.00(\mathrm{P}=0.262)$.

Tampak perbedaan kadar CA125 yang bermakna pada kedua kelompok luaran histopatologis, di mana CA125 pada kelompok histopatologis ganas memiliki rata-rata sebesar $736,02 \pm 1361,590$ dan CA125 pada kelompok jinak 208,21 $\pm 251,417$ $(\mathrm{P}=0.001)$. Perhitungan Skor RMI juga menunjukkan perbedaan pada kelompok histopatologis ganas (rata-rata skor RMI

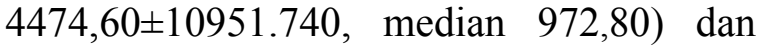
kelompok histopatologis jinak (rata-rata skor RMI 426,26 $\pm 353,314$, median 282,52)

Tabel 2 Distribusi Hasil Penelitian Berdasarkan Karakteristik Sampel

\begin{tabular}{|c|c|c|c|}
\hline \multirow[b]{2}{*}{ Variabel } & \multicolumn{2}{|c|}{ Kelompok } & \multirow[b]{2}{*}{ Nilai $\mathbf{P}$} \\
\hline & $\begin{array}{l}\text { Ganas } \\
\mathrm{N}=156\end{array}$ & $\begin{array}{l}\text { Jinak } \\
\mathrm{N}=34\end{array}$ & \\
\hline Usia & & & 0,262 \\
\hline Mean \pm Std & $44,17 \pm 13,660$ & $43,20 \pm 15.845$ & \\
\hline Median & 45,00 & 41,00 & \\
\hline Range (min-max) & $13,00-81,00$ & $20,00-80,00$ & \\
\hline Kategori Usia & & & 0,373 \\
\hline$<20$ tahun & $6(3,8 \%)$ & $0(0,0 \%)$ & \\
\hline 20-40 tahun & $45(28,8 \%)$ & $17(50,0 \%)$ & \\
\hline$>40$ tahun & $105(67,3 \%)$ & $17(50,0 \%)$ & \\
\hline CA125 & & & $0,001 * *$ \\
\hline Mean \pm Std & $736,02 \pm 1361,590$ & $208,21 \pm 251,417$ & \\
\hline Median & 257,97 & 135,95 & \\
\hline Range (min-max) & $16.80-9934,00$ & $16,00-1230,00$ & \\
\hline RMI & & & $0,0001 * *$ \\
\hline Mean \pm Std & $4474,60 \pm 10951,740$ & $426,26 \pm 353,314$ & \\
\hline Median & 972,80 & 282,52 & \\
\hline Range (min-max) & $25,00-80000,00$ & $46,50-1369,60$ & \\
\hline IOTA Simple Rule & & & $0,0001 * *$ \\
\hline Malignant & $77(49,4 \%)$ & $1(2,9 \%)$ & \\
\hline Benign & $9(5,8 \%)$ & $33(97,1 \%)$ & \\
\hline Inconclusive & $70(44,9 \%)$ & $0(0,0 \%)$ & \\
\hline
\end{tabular}


dengan $\mathrm{P}=0.0001$.

Data kategorik pada tabel IOTA Simple Rules diuji dengan menggunakan uji statistika Chi-Square serta alternatif uji Kolmogorov Smirnov apabila asumsi Chi Square tidak terpenuhi. Nilai P pada variabel IOTA Simple Rules lebih kecil dari 0.05 (nilai $\mathrm{P}<0.05$ ). Dengan demikian dapat dijelaskan bahwa terdapat perbedaan proporsi yang signifikan secara statistik antara variabel IOTA Simple Rule pada kelompok pasien Ganas dan Jinak secara histopatologis.

Tabel 3 Perbandingan antara Klasifikasi Prediksi Keganasan Skor RMI dan Kelompok Luaran Histopatologis

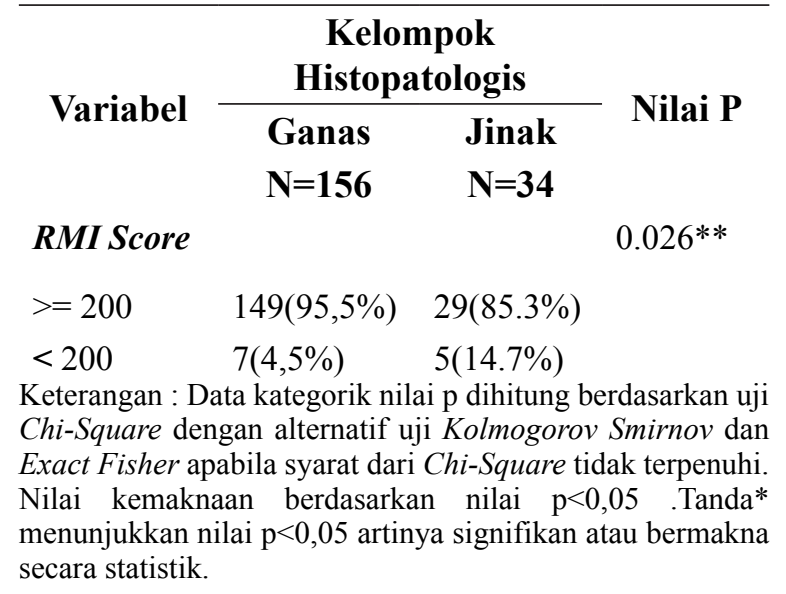

Tabel 3 menggambarkan model uji diagnostik menggunakan Skor RMI dengan hasil luaran histopatologisnya. Kelompok RMI $\geq 200$ menggambarkan kelompok yang diprediksi ganas dan kelompok RMI $<200$ merupakan kelompok dengan prediksi jinak. Dari uji statistik pada kelompok penelitian diatas diperoleh informasi nilai $\mathrm{P}$ yang lebih kecil dari 0,05 (nilai $\mathrm{P}<0,05$ ) yang berarti terdapat perbedaan proporsi yang signifikan secara statistik antara variabel kelompok Skor RMI pada kelompok kasus ganas dan jinak secara histopatologis. Nilai prediktif Skor RMI dengan cut-off point 200 tersebut di atas dapat dijelaskan sebagai berikut:

Sensitivitas $=\mathrm{a} /(\mathrm{a}+\mathrm{c})=149 / 156 \mathrm{x} 100 \%=$
$95,5 \%$

Spesifisitas $=d /(b+d)=5 / 34 \times 100 \%=14.7 \%$ Nilai Duga Positif $=a /(a+b)=149 / 178 \times 100 \%$ $=83,7 \%$

Nilai Duga Negatif $=d /(c+d)=5 / 22 \times 100 \%$ $=41,6 \%$

Akurasi $=(\mathrm{a}+\mathrm{d}) / \mathrm{N}=154 / 190 \times 100 \%=81,1 \%$

Berdasarkan Nilai Sensitivitas diatas sebesar 95,5\% menunjukkan nilai sensitivitas yang sangat kuat secara statistik, sedangkan nilai spesifitas sebesar $14,7 \%$ menunjukkan nilai spesifitas yang sangat lemah secara statistik. Untuk Nilai Duga Positif (NDP) diatas yaitu sebesar $83,7 \%$ menunjukan nilai Duga Positif(NDP) yang kuat secara statistik sedangkan Nilai Duga Negatif (NDN) sangat lemah yaitu sebesar $41,6 \%$ pada uji diagnostic ini.Untuk Nilai akurasi sebesar $81,1 \%$ menunjukkan tingkat nilai akurasi yang sangat kuat secara statistik.

Untuk IOTA Simple Rules, terdapat tiga klasifikasi dari hasi penilaian USG, yaitu kelompok Malignant, Benign, dan Inconclusive. Untuk uji diagnostik yang menggunakan kategori dua kelompok, yaitu uji diagnostik positif dan negatif, maka dilakukan pengukuran dengan dua cara, yaitu (1) menggabungkan kelompok inkonklusif bersama dengan kelompok ganas, dan (2) menggabungkan kelompok inkonklusif ke dalam kelompok jinak.

Uji statistik pada kelompok penelitian diatas informasi nilai $\mathrm{P}$ pada variabel IOTA Simple Rule lebih kecil dari 0.05 (nilai $\mathrm{P}<0.05)$. Berdasarkan Nilai Sensitivitas diatas sebesar 49,4\%, menunjukkan nilai Sensitivitas yang sangat lemah secara statistik, sedangkan Nilai Spesifitas sebesar $97,1 \%$ menunjukkan nilai Spesifitas yang sangat kuat secara statistik. Untuk Nilai Duga Positif (NDP) diatas yaitu sebesar 98,7\% menunjukan nilai Duga Positif (NDP) yang sangat kuat secara statistik sedangkan Nilai Duga Negatif 
Tabel 4 Perbandingan Antara Klasifikasi Prediksi Keganasan dengan IOTA Simple Rule dan Kelompok Keganasan Berdasarkan Luaran Histopatologis

\begin{tabular}{lccc}
\hline \multirow{2}{*}{ Variabel } & \multicolumn{2}{c}{ Kelompok } & \\
\cline { 2 - 3 } & Ganas & Jinak & Nilai P \\
& $\mathbf{N}=\mathbf{1 5 6}$ & $\mathbf{N = 3 4}$ & \\
\hline $\begin{array}{l}\text { IOTA Simple } \\
\text { Rule }\end{array}$ & & & $0,0001^{* *}$ \\
IOTA & $77(49,4 \%)$ & $1(2,9 \%)$ & \\
Malignant & & & \\
IOTA Benign & $79(50,6 \%)$ & $33(97,1 \%)$ & \\
atau & & & \\
Inconclusive & & \\
\hline
\end{tabular}

Keterangan : Data kategorik nilai p dihitung berdasarkan uji Chi-Square dengan alternative uji Kolmogorov Smirnov dan Exact Fisher apabila syarat dari Chi-Square tidak terpenuhi. Nilai kemaknaan berdasarkan nilai $\mathrm{p}<0,05$.Tanda* menunjukkan nilai $p<0,05$ artinya signifikan atau bermakna secara statistik.

Sensitivitas $=\mathbf{a} /(\mathbf{a}+\mathbf{c})=77 / 156 x \mathbf{1 0 0} \%=$ $49,4 \%$

Spesifisitas $=d /(b+d)=33 / 34 \times 100 \%$ $=97,1 \%$

Nilai Duga Positif $=\mathbf{a} /(\mathbf{a}+\mathbf{b})=77 / 78 \times 100 \%$ $=98,7 \%$

Nilai Duga Negatif $=d /(c+d)=33 / 113 x$ $100 \%=29,5 \%$

Akurasi $=(a+d) / N=111 / 190 x \quad 100 \%$ $=\mathbf{5 7 , 9 \%}$

(NDN) sangat lemah yaitu sebesar 29.5\% pada uji diagnostik ini. Untuk nilai akurasi sebesar 57,9\% menunjukkan tingkat nilai akurasi yang sangat lemah secara statistik.

Penghitungan nilai prediktif IOTA Simple Rule dengan menganggap hasil inkonklusif sebagai "Ganas" disajikan dalam tabel berikut.
Tabel 5 Perbandingan Antara Klasifikasi Prediksi Keganasan dengan IOTA Simple Rule dan Kelompok Keganasan Berdasar kan Luaran Histopatologis (Kelompok Inkon Klusif Di gabungkan Bersama Kelompok Ganas)

\begin{tabular}{lccc}
\hline \multirow{2}{*}{ Variabel } & \multicolumn{2}{c}{ Kelompok } & \\
\cline { 2 - 3 } & $\mathbf{N}=\mathbf{1 5 6}$ & $\mathbf{N}=\mathbf{3 4}$ & \\
\hline IOTA & & & Nilai P \\
Simple Rule & & & \\
IOTA & $147(94,2 \%)$ & $1(2,9 \%)$ & \\
Malignant or & & & \\
Inconclusive & & & \\
IOTA Benign & $9(5,8 \%)$ & $33(97,1 \%)$ & \\
\hline
\end{tabular}

Keterangan : Data kategorik nilai p dihitung berdasarkan uji Chi-Square dengan alternative uji Kolmogorov Smirnov dan Exact Fisher apabila syarat dari Chi-Square tidak terpenuhi. Nilai kemaknaan berdasarkan nilai $\mathrm{p}<0,05$.Tanda* menunjukkan nilai $p<0,05$ artinya signifikan atau bermakna secara statistik.

Sensitivitas $=a /(a+c)=147 / 156 x 100 \%=$ $94,2 \%$

Spesifisitas $=d /(b+d)=33 / 34 \times 100 \%$ $=97,1 \%$

Nilai Duga Positif $=\mathbf{a} /(\mathbf{a}+\mathbf{b})=$ $147 / 148 \times 100 \%=99,3 \%$

Nilai Duga Negatif $=d /(c+d)=33 / 42 x$ $100 \%=78,6 \%$

Akurasi $=(\mathrm{a}+\mathrm{d}) / \mathrm{N}=180 / 190 \mathrm{x} \quad 100 \%$ $=94,7 \%$

Untuk analisis pada data kategorik pada tabel diatas diuji dengan menggunakan uji statistika Chi-Square yaitu IOTA Simple Rule serta alternatif uji Exact Fisher apabila asumsi Chi Square tidak terpenuhi.

Hasil uji statistik pada kelompok penelitian diatas diperoleh informasi nilai $\mathrm{P}$ pada variabel IOTA Simple Rule lebih kecil dari 0.05 (nilai $\mathrm{P}<0.05$ ) yang berarti signifikan atau bermakna secara statistik dengan demikian dapat dijelaskan bahwa 
terdapat perbedaan proporsi yang signifikan secara statistik antara variabel IOTA Simple Rule pada kelompok pasien Ganas dan Jinak.

Berdasarkan Nilai Sensitivitas di atas sebesar 94,2\% menunjukkan nilai Sensitivitas yang sangat kuat secara statistik, sedangkan Nilai Spesifitas sebesar 97,1\% menunjukkan nilai Spesifitas yang sangat kuat secara statistik.

Untuk Nilai Duga Positif (NDP) di atas yaitu sebesar 99,3\% menunjukan nilai Duga Positif (NDP) yang sangat kuat secara statistik sedangkan Nilai Duga Negatif (NDN) sedang yaitu sebesar $78,6 \%$ pada uji diagnostik ini.Untuk Nilai akurasi sebesar 94,7\% menunjukkan tingkat nilai akurasi yang sangat kuat secara statistik.

\section{Pembahasan}

Paparan data di atas menggambarkan nilai prediktif IOTA Simple Rule dan Skor RMI 2 yang dilakukan di RSHS. Uji diagnostik terhadap skor RMI 2 yang dihitung pada pasien-pasien dengan tumor ovarium di RSHS menunjukkan nilai sensitivitas yang cukup baik, yaitu 95,51\%, namun nilai spesifisitas yang didapatkan rendah, yaitu 14,71\%.Uji diagnostik IOTA Simples Rule dengan menganggap seluruh kasus yang hasil pemeriksaan USG nya inkonklusif sebagai ganas menghasilkan nilai sensitifitas dan spesifisitas yang cukup baik, yaitu masingmasing $94,23 \%$ dan $97,06 \%$. Simpulan sensitivitas dan spesifisitas klasifikasi IOTA Simple Rules lebih baik dibandingkan dengan skor RMI dalam memprediksi keganasan suatu tumor ovarium.

\section{Saran}

Sistem klasifikasi IOTA Simple Rules memberikan luaran hasil ganas, jinak, dan inkonklusif. Pada penelitian ini digunakan penyederhanaan dengan menggabungkan tiga kelompok luaran menjadi dua kelompok untuk melakukan uji diagnostik sistem IOTA Simple Rules sebagai evaluasi penggunaannya di RSHS. IOTA telah mengembangkan model IOTA Adnex untuk follow up lebih lanjut mengenai kasus-kasus dengan hasil inkonklusif. Perlu dilakukan studi lebih lanjut terhadap kasus-kasus dengan hasil inkonklusif pada sistem pengkategorian IOTA Simple Rules.

\section{Daftar Pustaka}

1. Ulusoy S, Akbayir O, Numanoglu C, Ulusoy N, Odabas E, Gulkilik A. The risk of malignancy index in discrimination of adnexal masses. Int J Gynecol Obstet. 1 Maret 2007;96(3):186-91.

2. Reid BM, Permuth JB, Sellers TA. Epidemiology of ovarian cancer: a review. Cancer Biol Med. Februari 2017;14(1):9-32.

3. Ferlay J, Soerjomataram I, Dikshit R, Eser $\mathrm{S}$, Mathers C, Rebelo M, et al. Cancer incidence and mortality worldwide: Sources, methods and major patterns in GLOBOCAN 2012. Int J Cancer. 1 Maret 2015;136(5):E359-86.

4. Aziz AB, Najmi N. Is Risk Malignancy Index a Useful Tool for Predicting Malignant Ovarian Masses in Developing Countries? Obstet Gynecol Int. 21 Juni 2015;2015:951256.

5. Sayasneh A, Wynants L, Preisler J, Kaijser J, Johnson S, Stalder C, et al. Multicentre external validation of IOTA prediction models and RMI by operators with varied training. Br J Cancer. 25 Juni 2013;108(12):2448-54.

6. Timmerman D, Testa AC, Bourne T, Ameye L, Jurkovic D, Van Holsbeke C, et al. Simple ultrasound-based rules for the diagnosis of ovarian cancer. Ultrasound Obstet Gynecol. Juni 2008;31(6):681-90.

7. Yamamoto Y, Tsuchida A, Ushiwaka T, Nagai R, Matsumoto M, Komatsu J, et al. Comparison of 4 Risk-of-Malignancy 
Indexes in the Preoperative Evaluation of Patients With Pelvic Masses: A Prospective Study. Clin Ovarian Other Gynecol Cancer. 1 Desember 2014;7(12):8-12.

8. Schorge JO. Epithelial Ovarian Cancer. In: Hoffman BL, Schorge JO, Bradshaw KD, Halvorson LM, Schaffer JI, Corton MM, editor. Williams Gynecology. 3rd Ed. New York: McGraw Hill Professional; 2016.

9. Berek JS, Friedlander ML, Hacker NF. Germ Cell and Nonepithelial Ovarian Cancer. In: Berek JS, Hacker NF, editor. Berek \& Hacker's Gynecologic Oncology. Philadelphia: Wolters Kluwer; 2015. hal. 530-59.

10. Buderer NMF. Statistical Methodology: I. Incorporating the Prevalence of Disease into the Sample Size Calculation for Sensitivity and Specificity. Acad Emerg Med. 1 September 1996;3(9):895-900.

11. Malhotra RK, Indrayan A. A simple nomogram for sample size for estimating sensitivity and specificity of medical tests. Indian J Ophthalmol. 2010;58(6):519-22.

12. Pennsylvania State University. Comparing Two Diagnostic Tests [Internet]. [dikutip 10 Desember 2018]. Tersedia pada: https://onlinecourses.science.psu.edu/ stat509/node/152/ 